\title{
TAUTINIO STILIAUS PAIEŠKOS VLADIMIRO DUBENECKIO VISUOMENINIUOSE INTERJERUOSE
}

\author{
Lina Preišegalavičienè
}

\begin{abstract}
$U A B$ ARKIJA vadove, interjero architekte, Savanoriu pr. 184, Kaunas 44150, Lietuva, El.paštas prei.lina@gmail.com
\end{abstract}

Iteikta 20100512

\begin{abstract}
Santrauka. Straipsnis skirtas žinomam tarpukario Lietuvos architektui, dailininkui, scenografui ir pedagogui Vladimirui Dubeneckiui (1888-1932). Rusų kilmės menininkas, gyvenęs ir dirbęs Kaune 1919-1932 m., paliko Lietuvai nemažą kūrybinị palikimą. Vienas iš išskirtinių V. Dubeneckio kūrybinès biografijos bruožų tas, kad, būdamas ne lietuvis, jis tapo pirmuoju tautinio stiliaus ieškotoju Lietuvoje. Straipsnyje aptariama V. Dubeneckio kūrybos dalis, kurioje atsispindèjo tautinio stiliaus paieškos visuomeniniuose interjeruose. Straipsnio apžvalgai atrinkti trys ryškiausi V. Dubeneckio projektuoti interjerai (Karmèlavos bažnyčia - 1919 m., Frumkinų parduotuvė - 1922 m. ir „Lietuvos“ viešbutis - 1925 m.) bei jų sąveikos su tarpukario laikotarpiu architektūroje besireiškusiu tautiniu stiliumi, kartu aptariamas visuomeninio interjero reprezentatyvumo aspektas kaip vienas būdingiausių konceptualių interjero siekių.
\end{abstract}

Reikšminiai žodžiai: tarpukario interjeras, interjerų istorija, baldų istorija, tautinis stilius, tautiškumas, Vladimiras Dubeneckis.

\section{Ivadas}

Kad interjeras ${ }^{1}$ yra meninè sąvoka, šiandien nekyla abejonių. Šiuolaikiniuose žurnaluose ir laikraščiuose žodis interjeras minimas dažnai, o tarpukario Lietuvos spaudoje terandame tokius terminus kaip vidaus i̇rengimas (Valentukonis 1937), kambario ìrengimas (Ramoves rūmai... 1937), kambario užduotis, paskirtis (Margaitis 1937), vidaus dekoravimas (Senesnio tipo architektūros... 1937) Žmonès, kuriantys vidaus aplinką, vadinti projektuotojais, architektais-dailininkais, amatininkais-dekoratoriais, dažytojais-dekoratoriais

\footnotetext{
1 Sąvoka interjeras kildinama iš lotynų kalbos žodžio interior Vèliau ją perima prancūzai - interieur - ir vartoja tapybos žanrui, kuriame vaizduojamas namas ar patalpos vidus, apibūdinti. Vèliau šia sąvoka apibrèžiamas meniškai sukurtas ir apipavidalintas pastato patalpos vidus ir jo ịrenginiai (Tarptautiniu žodžiu žodynas. $2008 \mathrm{~m}$. Vilnius, p. 325; Lietuviškoji tarybine enciklopedija. 1978 m. 4 t., Vilnius), taip pat pabrèžiamas meninis, kūrybinis interjero pradas: meniškai suformuota ir apipavidalinta vidaus erdve ir jos įrenginiai. Svarbiausi komponentai yra erdvè (vientisa arba zonuota), ịranga (baldai, prietaisai) ir dekoras (paveikslai, skulptūros, kilimai, sienų tapyba, mozaika, vitražas).
}

(Valentukonis 1937). Tokių šiuolaikinių terminų, kaip interjero dizaineris ar interjero architektas, nerandame. Interjero, kaip akademinio meno sąvokos, atsiradimą Lietuvoje galima būtų susieti su data, kai Vilniaus valstybiniame Dailes institute, pokario metais isteigtame architektūros fakultete, architektūros kompozicijos ir projektavimo katedra. $1964 \mathrm{~m}$. perorganizuojama: pradeda ruošti interjero ir ịrengimu specialistus. Atitinkamai pakeičiamas ir katedros pavadinimas: Interjero ir įrengimu katedra (Morkytė 1981).

Nepaisant interjero kaip meno srities sąlyginio naujumo, tarpukario architektų darbuose, kaip ir bet kurios kitos epochos darbuose, interjerams buvo skiriamas gan didelis demesys. Visgi iki šiol Lietuvos tarpukario interjerų istorija tyrinèta mažai. Trumpus aprašymus apie architektūros paveldo (istorinių) interjerų suplanavimą, apdailos medžiagas galime rasti Jolitos Kančienès tekstuose apie Kauno tarpukario architektūrą. Epizodinè informacija ir tyrinejimo šaltiniai nurodyti Nijolès Lukšionytės Kauno architektūros analizèse. 
Detalesnę informaciją apie tarpukario interjerus tyrinètojai pateikia moksliniuose straipsniuose: lietuvišku baldų istorijos fragmentą randame Ritos Škiudienès straipsnyje „Lietuvos banko baldai“" Išskirtinai tautinio interjero stiliaus fenomenui dedikuotas Lijanos Šatavičiūtès straipsnis „Tautinio stiliaus stereotipai tarpukario Lietuvos interjeruose ${ }^{\text {“3 }}$. Publikacijose apie dailiujų amatų sajūidị tarpukario Lietuvoje ${ }^{4}$ buvo nagrinètos tautines tapatybès paieškos tarpukario namų apyvokos daiktuose ir interjero aksesuaruose ${ }^{5}$. Pavieni istorinio interjero aprašymą yra publikavusi Sigute Imbrasaite „Maironio salonai“" Algimantas Mačiulis, rašydamas apie tautines architektūros paieškas, palietė tautinio interjero klausimą ir atskleidè architektūros stilių plètotei pavojingas, neigiamas tautiškumo savybes - eklektiką ir tiesmuką imitaciją (Mačiulis 1998).

Nepaisant publikacijų gausos apie V. Dubeneckio veiklą Lietuvoje, jo kūryba tirta gan fragmentiškai. Apie architektą šiokios tokios informacijos galima rasti amžininkų tekstuose: Mykolas Songaila, Paulius Galaunè rašè apie architekto gyvenimo ir kūrybinès biografijos faktus, minejjo kai kuriuos asmenybès ir charakterio bruožus. V. Dubeneckis buvo minimas ir vèlesniuose tarpukario architektūros raidos aprašymuose. Tekstai sintetiniai, gilesnio, paremto archyviniais duomenimis tyrimo nèra. Juozas Jurginis, Eduardas Budreika, Juozas Baršauskas, Eugenijus Gūzas, Nijolè Lukšionytė, Jolita Kančienė bei Morta Baužienė yra rašę apie V. Dubeneckio biografijos faktus ir architektūros kūrybinị palikimą. Minètų autorių straipsniuose išsamesnio interjerų aprašymo nepavyko aptikti, juose lakoniškai užsiminta, pvz., kad buvo projektuoti baldai ar interjeras <...> (Lukšionytė 2001: 50). $1988 \mathrm{~m}$. spalio $25 \mathrm{~d}$. Lietuvos statybos ir architektūros mokslinio tyrimo institute vyko mokslinè konferencija, skirta V. Dubeneckio gyvenimui ir kūrybai nagrinèti. Septynių pranešimų medžiaga buvo atspausdinta atskiru leidiniu. Tautinio stiliaus architektūros tema aptarta: Vytauto Petrušonio pranešime „Apie kai kuriuos V. Dubeneckio kūrybinio mąstymo

\footnotetext{
2 Škiudienè, R. 2004. Lietuvos banko baldai, Menotyra 36: 50-55.

3 Šatavičiūtè, L. 2002. Tautinio stiliaus stereotipai tarpukario Lietuvos interjeruose, Menotyra 3(28): 51-57.

4 Šatavičiūtè, L. 2007. Dailininkas ar amatininkas? Menininkas ir dailiųjų amatų sąjūdis tarpukario Lietuvoje, Kultūrologija 15: 244-272.

5 Šatavičiūtè, L. 2007. Stiliaus varžtuose: tautinès tapatybès paieškos tarpukario namu pramonès dirbiniuose, Menotyra 14(2): 20-31

6 Imbrasaite, S. 1999. Maironio salonai, Namas, kuriame gyvenu 9(18): 25-27.
}

ypatumus“, J. Kančienės „Tautinio stiliaus ieškojimai V. Dubeneckio kūryboje" ir Algimanto Miškinio „Kelios mintys apie Karmèlavos bažnyčios architektūrą" (Mokslinès konferencijos... 1988). Tad šio straipsnio tikslas yra pratęsti Lietuvos architektų ir tyrinètojų konferencijos metu užsibrèžtą V. Dubeneckio palikimo tyrinejiima, populiarinima ir įamžinima (Miškinis 1988) bei kiek įmanoma detaliau aptarti dalị išlikusių architekto visuomeninių interjerų, ivvertinant tuo metu vyravusių objektyvių politinių ir kultūrinių sąlygų įtaką kūrybos rezultatui. Nors straipsnyje pristatomas tik menkas plataus reiškinio fragmentas, tačiau atsižvelgiant ị V. Dubeneckio reikšmę pirmuoju tarpukario dešimtmečiu, galima daryti prielaidą, kad išlikę interjerų dokumentai nemaža dalimi atspindi tarpukario Lietuvai charakteringą projektavimo specifiką ir vyravusią stilistiką. Išlikę brèžiniai ir eskizai atspindi $\mathrm{XX}$ a. pradžioje pasireiškusio tautinès pakraipos dailès ir architektūros sąjūdžio pèdsakus. Tautiškumą reprezentuojančios architektūros paieškos buvo tik dalis proceso, kuris plačiai skleidèsi tarp daugelio Europos tautų, ypač tarp mažai žinomų ir prislopintų. Naujo dailès ir architektūros stiliaus atsiradimo reikalavo $\mathrm{XX}$ a. I pusès Lietuvos kultūrinio ir politinio gyvenimo realijos. Tautinio stiliaus susiformavimo prielaidos, jo raiškos aspektai plačiai aptarti monofrafijose: „Dailè ir Valstybė. Dailés gyvenimas Lietuvos respublikoje 1918-1940“ (Jankevičiūtè 2003) bei „Modernizmo link“.(Mulevičiūtė 2001). Greta valstybès ideologijos itakos tautinio stiliaus atsiradimui, reikia atkreipti dèmesį i V. Dubeneckio asmeninị požiūrị, jog senoves architektūra, sodžiaus ornamentai, kiti liaudies kūrybos paminklai yra išminties ir kürybinio įkvépimo šaltinis. V. Dubeneckis ịvardino ši procesą minties skolinimu $<\ldots>$ be procentu ir sumos gražinimo $<. . .>$ (Dubeneckis 1925). 1927 m. Kauno meno mokykla Dubenecki pa$k v i e t e$ profesoriauti $\langle\ldots$, , šiam talentingam menininkui kolegos pavedè uždavinị: išvystyti lietuviška stiliu ornamentikoj ir architektūros formose (Dirgèla 1925). Nors V. Dubeneckis ir buvo ne lietuvis, ji galima laikyti pirmuoju Lietuvos tautinio stiliaus ieškotoju (Galaunè 1970). Interjero projektai yra dalis šaltinių, kur šis procesas atsispindi.

\section{Karmèlavos bažnyčios projektas - 1919 m.}

Medinè Karmèlavos bažnyčia - pirmasis V. Dubeneckio projektas, kuriam ịkvèpimo sėmèsi iš liaudies architektūros. Bažnyčia sudege Antrojo pasaulinio karo metu. Šiuo metu yra išlikusi tik archyvinè medžiaga. Bažnyčios architektūroje atsispindi savaip 
interpretuoti medinių varpinių, koplyčių motyvai, juntamas senosios architektūros proporcijų ritmas ir darna. Praejus 19-ai metų nuo tada, kai buvo sukurtas projektas, apie V. Dubeneckio tautinio stiliaus paieškas Paulius Galaunè rašè: Nuo krikščionybès priemimo iki pasaulinio karo Lietuvoje tiek daug buvo statyta mediniu bažnyčiu, tad ar gali būti taip, kad 500 metu laikotarpy nesudarytu savu tradiciju, nesurastu savu stilistiniu savybiu. V. Dubeneckis ieško tų elementu, ieško atkakliai visais įmanomais büdais $<\ldots>$ kiekviena proga lanko provincijos miestelius, kad tiktai daugiau pamatyti gyvu pavyzdžių, surasti charakteringu savybiu. Nori, kad viskas tatai ne vien išorine forma būty surištas, bet ir istorinio akiračio dvasia. Iščia tas eskizu gausumas, vis nesitenkinimas <...> (Galaunè 1937).

Nacionalinio M. K. Čiurlionio dailès muziejaus P. Galaunès rinkiniuose saugomos išlikusios Karmèlavos bažnyčios fasadų ir interjerų eskizų fotokopijos ${ }^{7}$. Eskizai buvo piešti švino pieštuku, fasadai, planas, bokštų ir centrinès navos pjūviai bei barokinio stiliaus altoriaus projektas buvo braižyti tušu. Yra išlikę piešiniai - interjero vaizdai $i$ altoriaus ir vargonų puses. Nesigilinant į bažnyčios išorès architektūrą, vis dèlto reikètų pastebèti vietas, kurias P. Galaunè $1937 \mathrm{~m}$. juvardino tarpukario dialektui būdingu terminu - istorinio akiračio dvasia (Galaunè 1937): du daugiatarpsniai bokštai pagrindiniame fasade yra artimi baroko stiliui, bet šiam stiliui nebūdinga bokštų forma, o ypač apatinis, į apačią platėjantis, dailylentèmis dengtas tarpsnis. Gali būti, kad Lietuvos medinès varpinès darè ịtaką nuožulnių V. Dubeneckio projektuotų bokštų tarpsnio atsiradimui ${ }^{8}$. Manoma, kad iš lietuvių liaudies architektūros buvo pasiskolintos (Dubeneckis 1925: 93) viršutinio bokšto arkinio tarpsnio formos. Panašu sienų ir stogo aukščiu santyki galètume aptikti kluonu architektūroje. Formu paprastumas ir funkcionalumas, pagrindine konstrukcinè ir apdailos medžiaga medis: visa tai - lietuviško kaimo architektūros bruožas. Karmèlavos bažnyčios projekte išryškejja architekto idèjinè ir kūrybinè kryptis: Lietuvos barokas yra kaip profesionalios architektūros šaltinis ir lietuvių liaudies architektūra, kaip tautiškumo šaltinis.

Bažnyčios planinè struktūra tradicinè - tai yra stačiakampio plano, trinavè bažnyčia. Centrinès navos dalies gale, virš pagrindinio iejejimo, taip, kaip būdinga

\footnotetext{
NČDM (Nacionalinis M. K. Čiurlionio dailès muziejus); APGN (Adelès ir Pauliaus Galaunių namai); GNF (Galaunès nuotraukų fondas 1566-1572).

8 Jankevičienè, A. 2007. Lietuvos medinès bažnyčios, koplyčios ir varpiness. Vilnius. VDA (žr. 268 pav. - Grūstès varpiné; 269 pav. - Rozalimo varpiné; 270 pav. - Vaiguvos varpiné; 271 pav. - Beržoro varpiné; 273 pav. - Platelių varpinè).
}

bažnyčių suplanavimui ${ }^{9}$, irengtas stačiakampès formos vargonų choras (1 pav.). Palubèje, iš abiejų pusių, nuo navos ji skiria arkos ir balkonèlis - barokinio stiliaus baliustrada. Medinèms bažnyčioms nebūdingas sprendimas yra tai, kad virš arkos suformuotos kelios eilès karnizų ir viršutinè pertvaros dalis puošta barokinio frontono fragmentu, kurio šonas užbaigtas masyvaus $S$ formos ornamentine briauna. Apačioje balkonèlis remiasi į akliną prienavio sieną, kurios centrą akcentuoja centrinio įejimo durys. Durų angokraščiai puošti barokinio dekoro karnizų apvadais ir frontonèliu, kurie būdingesni mūriniams pastatams, bet ne medinèms bažnyčioms. Sienoje prie centrinio įejjimo durų ikomponuotas būtinas sakralinio interjero atributas - šventinto vandens indas, kuris nupieštas barokinès kriauklès formos. Vaizde ị vargonų pusę matosi šio durų frontonèlio, karnizų ir chorą atitveriančio frontonų fragmentų derinys, taigi atsiveria barokiniam interjerui charakteringas vaizdas.

Vaizde ị altoriaus pusę matosi, kad buvo suprojektuota medinè smailios arkos konstrukcija ir šios medinès konstrukcijos jungčių detalizacija (2 pav.).

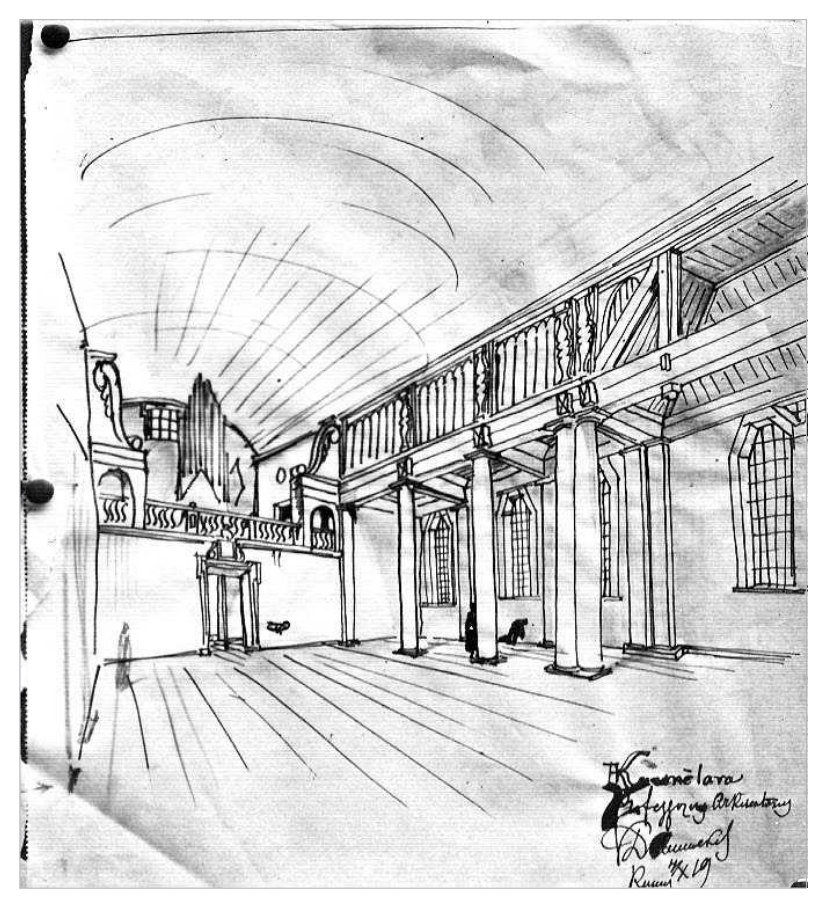

1 pav. Karmèlavos bažnyčios interjero vaizdas į vargonų pusę, 1919 m., NČDM. APGN.1571

Fig. 1. Karmelava Church interior, view towards the organ side, 1919.

9 Jankevičienè, A. 2007. Lietuvos medinès bažnyčios, koplyčios ir varpines. Vilnius, 23-34. 


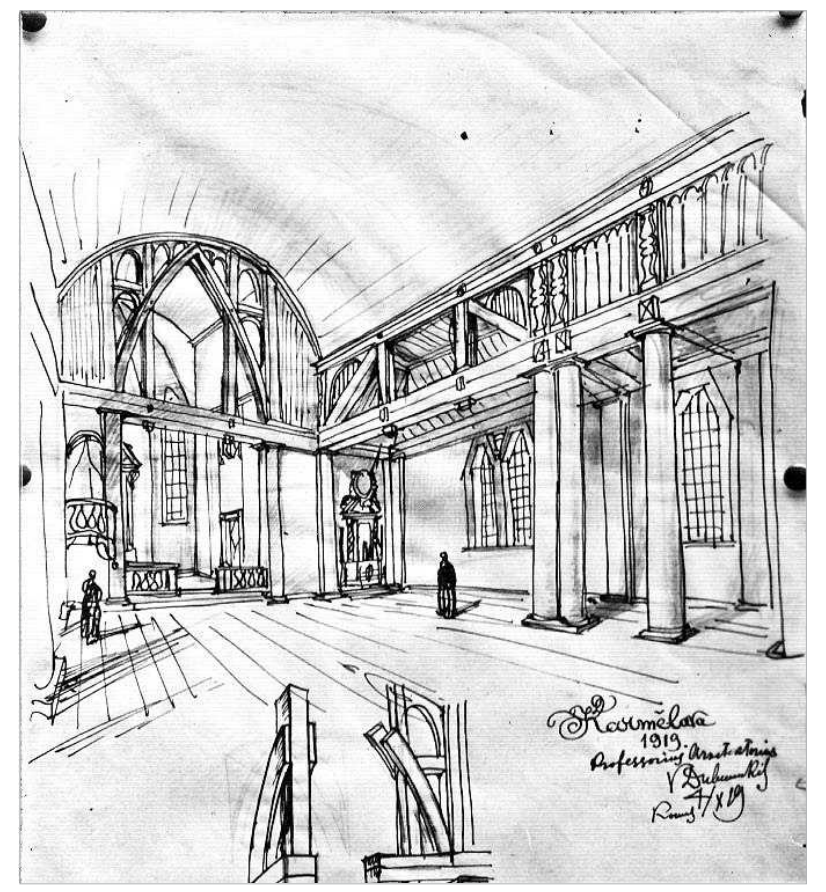

2 pav. Karmèlavos bažnyčios interjero vaizdas į altoriaus pusę, 1919 m., NČDM. APGN.1571

Fig. 2. Karmèlava Church interior, view towards the altar side, 1919.

Manoma, kad architekto panaudota smaili arka galèjo būti susijusi su XIX a. pabaigoje ir XX a. pradžioje lietuvių liaudies sakralinėje architektūroje naudota neogotikine stilistika: smailiaarkiai langai, atitinkamos formos sakyklos, klauptai ir ažūrinè altorių apdaila (panašias formas aptinkame Eržvilko ${ }^{10}$, Salų ${ }^{11}$, Marcinkonių bažnyčiose ${ }^{12}$ ). Centrinès navos abiejose pusèse - medinès kolonos, papuoštos lakoniškais kvadratiniais kapiteliais ir tokiomis pat kolonų bazemis, laiko balkonèlį su tekinto medžio barokinių formų turèklu. Po balkonèliu, už kolonų, suformuotos $3,52 \mathrm{~m}$ pločio (atstumas tarp ašių) šoninès navos. Liaudiškoms medinèms bažnyčioms yra būdingi pamažinti matmenys, lyginant su sakraline mūro architektūra. Remiantis bažnyčios interjero vaizdais, galima teigti, kad sienų išklotinè buvo skaidoma kolonų ritmą atitinkančiais piliastrais. Piliastrų fasadiné plokštuma ir šonai - lygios plokštumos, be dekoro, o tai yra būdinga lietuviškajam mūro pastatų barokui. Bazè ir kapitelis stačiakampès lygios plokštumos, dekoras nenaudoja-

\footnotetext{
${ }^{10}$ Jankevičienè, A. 2007. Lietuvos medinès bažnyčios, koplyčios ir varpines. Vilnius, 128-131.

11 Ten pat, 202-203.

12 Ten pat, 204-205.
}

mas. Šonines navas dengia medinių sijų konstrukcijos ir balkonèlio grindys. Tai yra charakteringas lietuviškų medinių kaimo koplytèlių ir liaudies architektūros bruožas.

Priekinę centrinès navos zoną priešais altorių žymi sugretinti kolona ir langai abiejose pusèse (3 pav.). Lietuvių medinèje sakralinèje architektūroje analogiškai komponuojami langai dažniausiai buvo naudojami pagrindiniame fasade, virš durų, kad būtų akcentuotas pagrindinis ièjimas ${ }^{13}$. O V. Dubeneckis netipiškai projektuoja sudvejintus langus, numatydamas juos šoniniuose fasaduose. Taip išsiskiria šoniniai altoriai ir priekinè navos dalis. Navos išplatejjimą priekinèje dalyje papildomai paryškina paaukštintos lubos. Vertikaliai išilginta langų proporcija su trapecijos formos angos viršumi buvo nebūdinga Lietuvos medinèms bažnyčioms, tuo labiau Lietuvos barokui - tai V. Dubeneckio sukurta netipiška forma, panaši i gotikines proporcijas. Aštuoniakampès, artimos ovalui, formos langai varpinių bokštuose, dekoruoti $S$ raidès barokiniais ornamentais, taip pat V. Dubeneckio sukurtas naujadaras, perfrazuojant barokinių mūro bažnyčių ovalius bokštų langus (4 pav.).

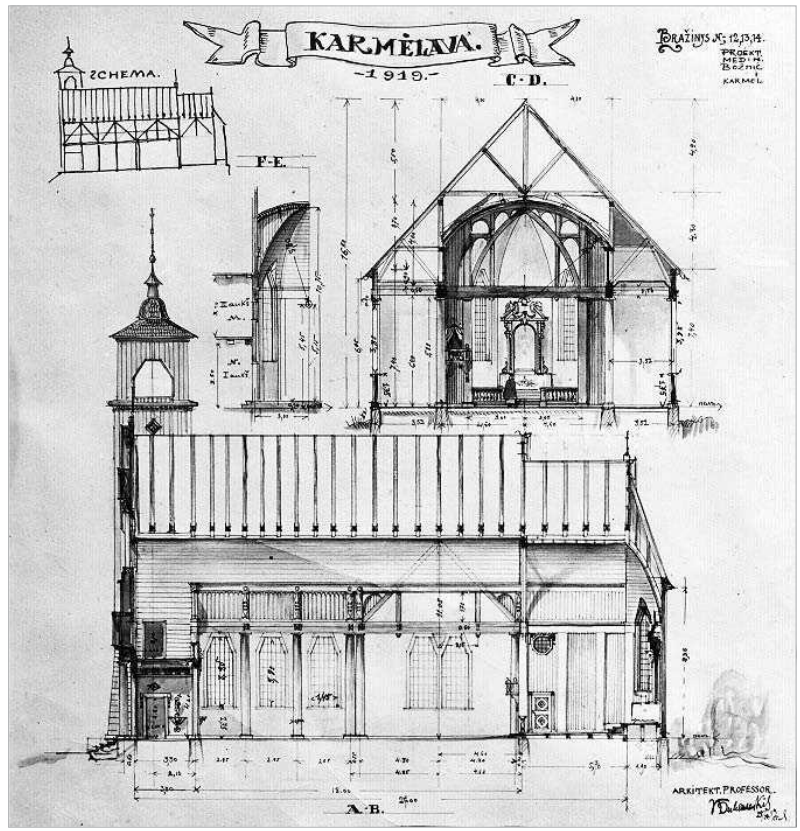

3 pav. Karmèlavos bažnyčios skersinis ir išilginis pjūviai, 1919 m., NČDM. APGN.1570

Fig. 3. Karmèlava Church, transverse and longitudinal sections, 1919.

13 Jankevičienè, A. 2007. Lietuvos medinès bažnyčios, koplyčios ir varpines. Vilnius: 80, 84, 90, 95. 


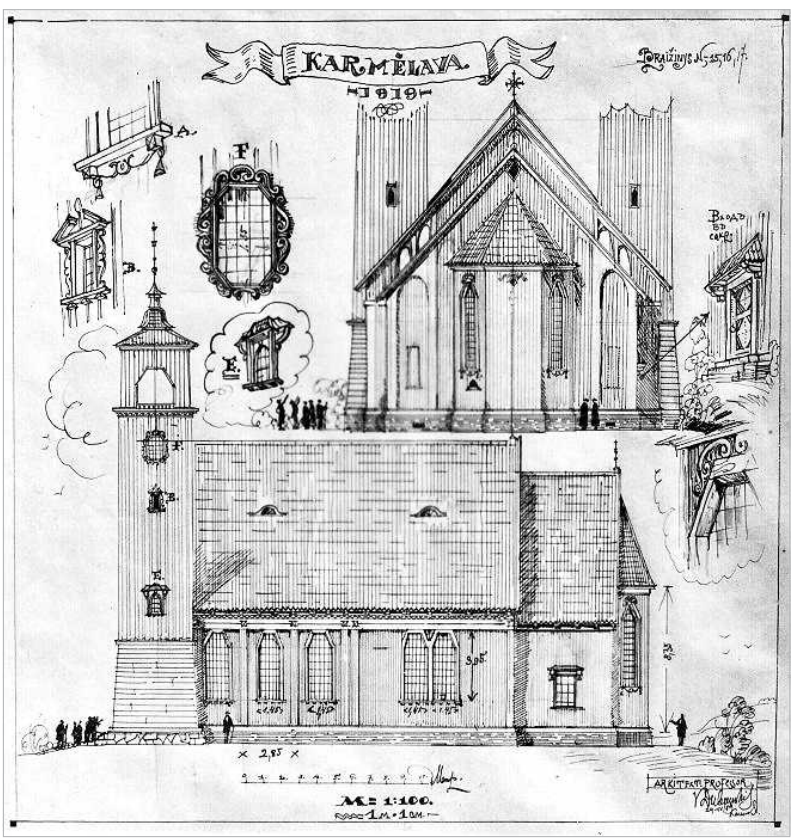

4 pav. Karmèlavos bažnyčios šoninis ir galinis fasadai. Langu ir duru angokraščiu puošybos detalizacija, 1919 m., NČDM. APGN.1569

Fig. 4. Karmèlava Church, side and back elevations. Ornamental detailing of the windows and doors, 1919.

Bažnyčios lubos - suformuotas cilindrinis skliautas $(R 5,60 \mathrm{~m})$, nedaug nužemèjantis apsidès zonoje, iš vidaus visas dengtas medinèmis dailylentèmis, visiškai paslepiant bažnyčios dvišlaičio stogo konstrukciją. Mažesnio ar didesnio skliauto, taip pat plokščių lubų apkalimas medinèmis dailylentèmis išilgai navos kryptimi - būdingas daugumai Lietuvos medinių bažnyčių.

Barokinių formų medinès detalès bažnyčios interjerui suteikia puošnumo. Apdailai naudojamas medis erdvei suteikia šiltumo įspūdị. Supaprastintų barokinių formų atkartojimas medyje - labai subtilus ir tam laikotarpiui naujas formos ir medžiagiškumo derinys, kurị galima būtų ịvardinti kaip tautinio stiliaus atradimą.

Prisimindamas Karmèlavos bažnyčios projektavimo ir statybos reikalus P. Galaunè rašè, kad meistrai, nesuprasdami, kaip viena ar kita jiems nauja konstrukciją atlikti, užsakytojams ịkalbinejo konstrukcijos sugalvota branguma ir siūlè savaip projekta traktuoti $<. . .>$. Lèšu trūkumas užsakytojus vertè prašyti projekto autoriu viska prastinti iki kraštutinumo (Galaunè 1937). Tad realizacija, įvykdyta neprisilaikant projekto, smarkiai nuvylè autorių. P. Galaunès nuomone, bažnyčios projektas, jei būtu igyvendintas tiksliai remiantis V. Dubeneckio brèžiniais, bütų puikiausias tradiciness lietuviškosios architektūros pavyzdys. Ir nenuostabu, nes A. Jaroševičiaus lietuviškų kryžiu albumas - kiekviena diena jo vartoma knyga, lietuviško stiliaus pradmeny evangelija (Galaunè 1970).

1922 m. Karmèlavos bažnyčiai architektas V. Dubeneckis suprojektavo barokinių formų altorių (5 pav.). Šis projektas skiriasi nuo pirmojo altoriaus varianto (1919 m.), kuris matosi pjūvio brèžinyje (3 pav.). Pirminio varianto barokinių formų altorius neturèjo lietuviškos tautodailès įtakos, kurią matome 1922-ųjų metų projekte. Kaip ir būdinga barokiniam stiliui, altorius išlieka puošnus ir sudarytas iš trijų tarpsnių: apatinis tarpsnis masyvus, tačiau fasadinès plokštumos švarumas yra artimas modernizmui; vidurinio tarpsnio puošnumas ir dinamiškas dekoras suteikia altoriui baroko stiliaus bruožų. Dekoras suformuotas iš puskolonių, piliastrų, apjuostų spiralesvirveles ornamentu: spirales arba virvelés ornamentus J. Basanavičius aprašè kaip ypač senus, naudotus dar iki

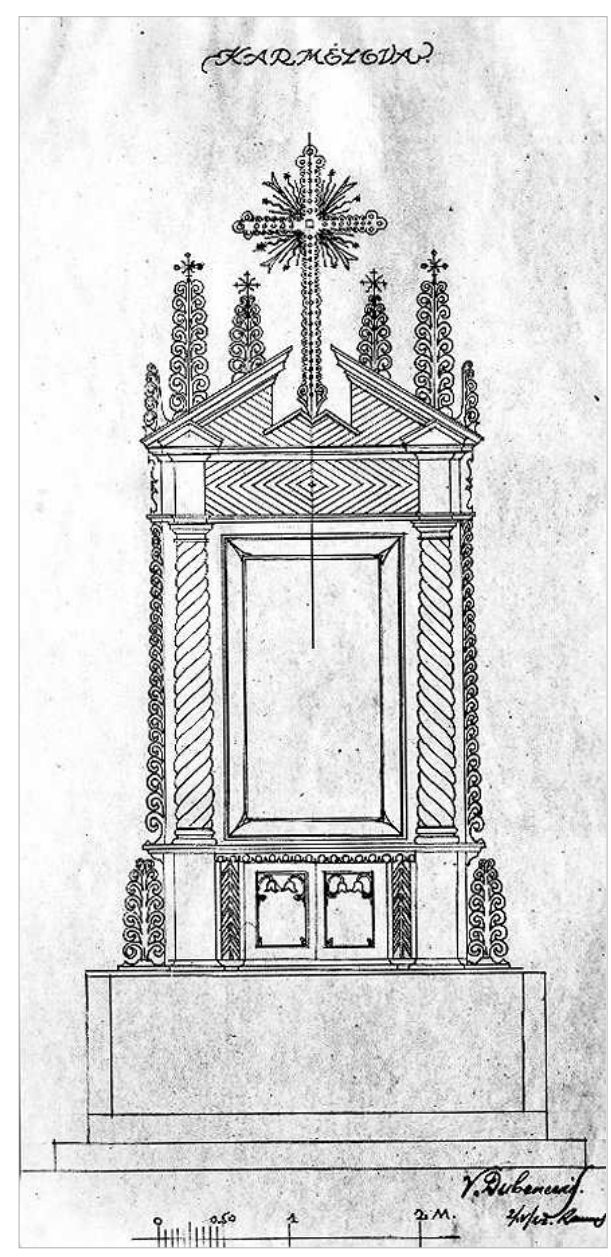

5 pav. Karmèlavos bažnyčios altorius, 1922 m., NČDM. APGN.1572

Fig. 5. Karmèlava Church, altar, 1922. 
krikščionybės, labai mėgiamus Lietuvoje ir dažnai naudojamus: <...> Virviu, spiraliu ornamentu randame ne tik pačiu kryžiu (piešinys Nr. 30), bet dar dažniau koplytèliu stulpelius (piliorèlius) dabintus (piešinys Nr. 16; 22; 29) (Basanavičius 1912). I viršų lengvejjantis augalinis banguotasis ornamentas puošia altoriaus šonus. Lygiai toki patị dekorą naudojo ir lietuvių dievdirbiai, drožę medinius kryžius ir stogastulpius: Jaroševičiaus albume Lietuvių kryžiai (piešinys Nr. 68) aptinkame toki ornamentą ${ }^{14}$. Naudojant tokị pat augalinị ornamentą formuojami dekoratyviniai bokšteliai, viršūnèje užsibaigiantys saulutès formos nedideliais kryželiais ir puošiantys iš abiejų pusių altoriaus stogelị bei centrinị kryžių. Centrinio kryžiaus masyvas išdailintas puslankiu ir skylučiu ažūru. Ši ornamentą aptinkame ir mediniuose stogastulpiuose ${ }^{15}$. Kryžius užpildytas saulutès ornamentu. Labai kuklus, lakoniškas, dviejų tulpeliu motyvas puošia altoriaus tabernakulio dureles. Tulpeles motyvo ornamentas (dar vadinamas lelijos motyvu) buvo ypač plačiai naudojamas kalvystės mene kaip metalinių kryžių galų dekoras arba kryžiaus-saulutès spindulių užbaigimas ${ }^{16}$. Tulpés ornamentas tautodailèje buvo plačiai naudojamas kaip audimo raštas bei skrynių ir spintų puošybos elementas ${ }^{17}$. Nulinkusios tulpès žiedo ornamentą aptinkame išdrožtą medyje, dekoruojant medinius stogastulpius ${ }^{18}$. Nors tulpés ornamentas i Lietuvą yra atklydęs iš kitur, tačiau yra traktuojamas kaip lietuvybès simbolis, jis siejamas su tautos praeitimi. P. Galaunès užrašytuose prisiminimuose bei kitų autorių publikacijose apie V. Dubeneckio kūrybą yra minima, jog architektas domejjosi lietuvių tautos menu, krašto kultūra, papročiais ir mitologija, todèl galima teigti, kad medeliu, kaip ir tulpių, motyvą altoriaus dekorui panaudojo sąmoningai kaip gyvybès medžio ir amžinojo gyvenimo simboli. V. Dubeneckio sukurti medeliai pakeičia neogotikiniu formų bokštelius, pinaklius, plačiai naudotus Lietuvos neogotikinių altorių ir vargonų puošyboje ${ }^{19}$. Tuo požiūriu Karmèlavos bažnyčios altorius yra savitas, tautiškas ir naujoviškas.

${ }^{14}$ Jaroševičius, A. 1912. Lietuvių kryžiai. Vilnius. Kryžius (piešinio Nr. 68).

${ }^{15}$ Jaroševičius, A. 1912. Lietuviu kryžiai. Vilnius. Kryžiai (piešinio Nr.: 19; 21; 31)

${ }^{16}$ Stravinskas, A.; Sakalauskas, M. 1992. Lietuviu liaudies menas. III kn. Mažoji architektūra. Vilnius. Kryžiai, pav.: 492-497; 502; 504; 509; 512-515; 532; 533; 539; 540; 542.

${ }^{17}$ Plačiau žr.: Keturka, A. 1987. Spalva lietuvių liaudies baldų puošyboje. Vilnius.

${ }^{18}$ Galaunè, P. Stogastulpiu ir koplytstulpiu tipizacijos lentele. Piešinių Nr.: 4; 5 (priedas prie knygos: Stravinskas, A; Sakalauskas, M. 1992. Lietuviu liaudies menas. III kn. Mažoji architektūra. Vilnius).

${ }^{19}$ Daugiau žr.: Gučas, R. 2009. Lietuvos vargonai - katalogas. Vilnius.
V. Dubeneckis nesiekè atkartoti žinomą ornamentą ar plačiai paplitusias formas. Altoriaus projektas, nors ir barokinès stilistikos, bet aiškiai rodo architekto paieškas sukurti naują, iki tol nematytą ir nenaudotą praeities ir tuometinio modernumo sintezę. Naujumo paieškas V. Dubeneckio kūryboje pabrèžè Mykolas Songaila: <...> Kūrybiniame darbe V. Dubeneckis nepripažino rutinos, nekentè vergiško pamégdžiojimo pavyzdžiu, <...> mokąs architektūroje logiškai galvoti, turédamas igimta skoni ir talenta, jis negalejo pasitenkinti trafaretu - jis kūré savaimingai, skoningai ir logiškai (Songaila 1934). V. Dubeneckio kūrybai charakteringas saikingas dekoras turèjo sąsajas su lietuvių liaudies architektūrai būdinga saikinga ir subtilia puošyba. Lyginant su laikotarpio analogais - saikingumas nebuvo būdingas tuometinių medinių kaimo bažnyčių interjerams, kurie dažnai būdavo nesaikingai perpildyti dekoro elementais, stiuko lipdiniais, ornamentais, spalvinga sienine tapyba, meno kūriniais, imitacija, kiču ir panašiai (Jankevičienè 2007).

Vos atvykęs gyventi ị Lietuvą, būdamas ne lietuvių tautybès, architektas Karmèlavos bažnyčios interjero projektu deklaravo savo įsitraukimą ị tuometinị Lietuvos kultūrini gyvenimą, kaip menininkas savo projektu V. Dubeneckis skelbè nacionalinių Lietuvos kultūros vertybių išsaugojimo idejją bei kūrybinę laisvę.

Tautinio stiliaus bruožai Karmèlavos bažnyčios projekte. Šiam projektui būdinga nesudètinga, planinè struktūra, lietuvių liaudies architektūros formos ir proporcijos. Sienų ir lubų apdailai buvo naudojamas apkalimas dailylentėmis. Medis - pagrindinè apdailos medžiaga. Saikingas dekoras ir saikingas puošnumas. Medžio raižiniuose naudojama liaudies ornamentika: tulpé, saulutè ir virvele bei barokinės voliutos, S formos, banguoto ornamento motyvai. Skirtingų architektūros stilių: baroko, gotikos ir liaudies architektūros sintezè naujų, iki tol nenaudotų formų atsiradimas.

\section{Frumkinų parduotuvè - $1922 \mathrm{~m}$.}

Apygardos teismo pastate (dabartine paskirtis Kauno miesto apylinkès teismas), priklausiusiame Iljos ir Rebekos Frumkinų ịpėdiniams, pirmajame aukšte buvo ịvairių krautuvių. Vienos parduotuvès interjerą buvo suprojektavęs V. Dubeneckis (Lukšionytė 2001: 82). Kauno apskrities archyve saugomi išlikę $1922 \mathrm{~m}$. projektuoto parduotuvès interjero eskizai ${ }^{20}$. Remiantis archyvo medžiaga, nedidelè, apie $50 \mathrm{~m}^{2}$ ploto, krautu-

\footnotetext{
${ }^{20}$ KAA (Kauno apskrities archyvas). F156 ap.1, b.8.
} 
vèlè turejjo būti įrengta pastato šiaurès vakarų kampinejje dalyje. Išlikę interjero eskizai leidžia susipažinti su interjero suplanavimu ir dekoro elementais.

Stačiakampio plano lubos visu perimetru dekoruotos karnizais. Karnizu juostų plotis derintas taip, kad pirmoji, išorinè, buvo plačiausia, trečioji, vidinè juosta - pati siauriausia. Lubų centre - vienas didelis pusapvalio, profiliuoto gaubto šviestuvas, esantis dekoratyvinès reljefinès rozetès centre. Ekspresyvią rozetès dekoravimo ornamentiką ${ }^{21}$ architektas derina su lubų karnizo geometrizuotų tulpelių ornamento juosta (6 pav.). Eskizuose matosi, kad šio interjero puošybai buvo ieškota ekspresyvios, geometrizuotos formos ornamentų, turinčių art deco stiliaus bruožų. Iš lauko pusès langai stačiakampès formos, o interjere formuojamos lengvos arkos, susijungiančios su dekoruotais tarplangių piliastrais (7 pav.). Piliastrai dekoruojami stilizuotu, stipriai išilgintu saulès spindulių ornamentu art deco maniera (7 pav.). Sienos išklotinę horizontaliai sudalina karnizo juosta. Visi penki ornamentų tipai: pirmasis - rozetė aplink šviestuvo gaubto apskritimą, antrasis - lubų plačiausias dekoratyvinis karnizas, trečiasis - pats stambiausias ornamentas, puošiantis

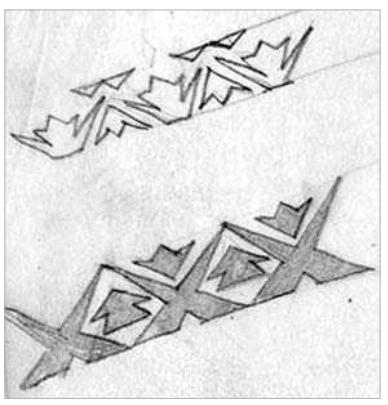

6 pav. Frumkiny parduotuvès ornamentika - luby karnizu dekoras, $1922 \mathrm{~m}$. KAA.F156 ap.1, b.8, I.12

Fig. 6. Frumkinai Store ornamentation, sketches of ornamentation for ceiling cornice, 1922.

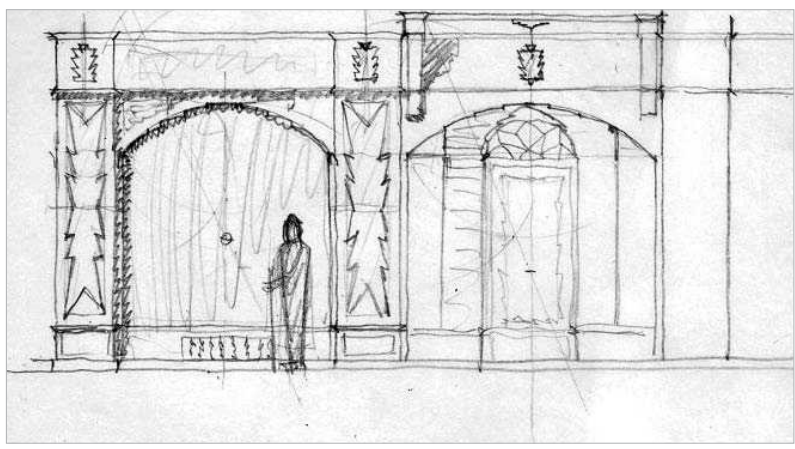

7 pav. Frumkinų parduotuvės ornamentika - sienų išklotinès eskizas, 1922 m., KAA.F156 ap.1, b.8, I.9

Fig. 7. Frumkinai Store ornamentation, sketch of interior elevation, 1922.

\footnotetext{
${ }^{21}$ KAA. F156 ap.1, b.8. Lap.21.
}

piliastrų priekinę plokštumą (7 pav.), ketvirtasis - pats smulkiausias išklotinès viršuje, virš karnizo (8 pav.), ir pagrindinis ornamentikos akcentas parduotuvès interjere - virš ièjimo durų ikomponuotas sieninis laikrodis (9 pav.) - yra derinami tarpusavyje. Nors eskizuose dominuoja dinamiška strèlès forma, vis dèlto tai - geometrizuotas tulpeles žiedo su lapeliais motyvas.

Tarp interjero eskizų yra išlikę ir aptakių, baroko voliutoms charakteringų formų. Tačiau dominuojančių ornamento linijų plastika ir proporcijos šiame interjero projekte neatkartoja kituose projektuose matytų formų. Kadangi nepavyko aptikti išlikusių nuotraukų su šios krautuvèlès interjeru, galima spèti, remiantis žiniomis apie tarpukario interjerų apdailos medžiagas, kad prabangus sienų išklotinių dekoras buvo tamsios spalvos medžio raižiniai sienų apdailos plokštėse. Lubos, puoštos karnizais ir ornamentų juosta, greičiausiai buvo dažytos baltai. Nedidelè ir jauki erdvé

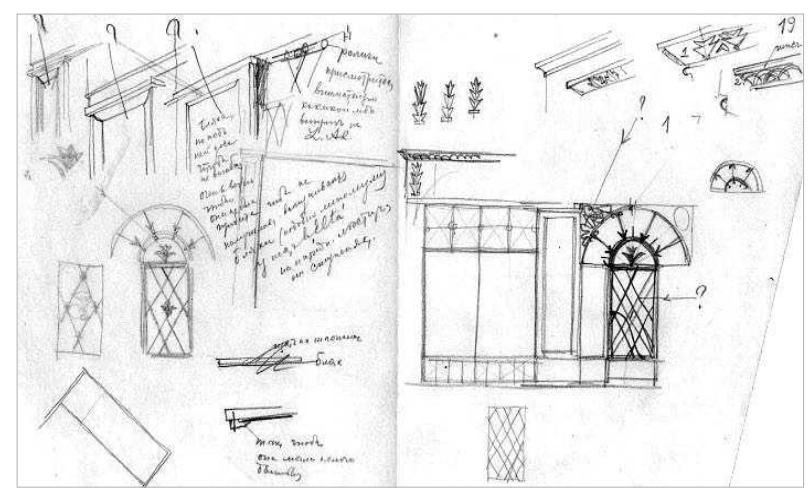

8 pav. Frumkinų parduotuvės ornamentika - sienų išklotinès ir karnizu dekoravimo eskizai, 1922 m., KAA. F156 ap.1, b.8, I.19

Fig. 8. Frumkinai Store ornamentation, sketches of interior elevation and cornice decoration, 1922.

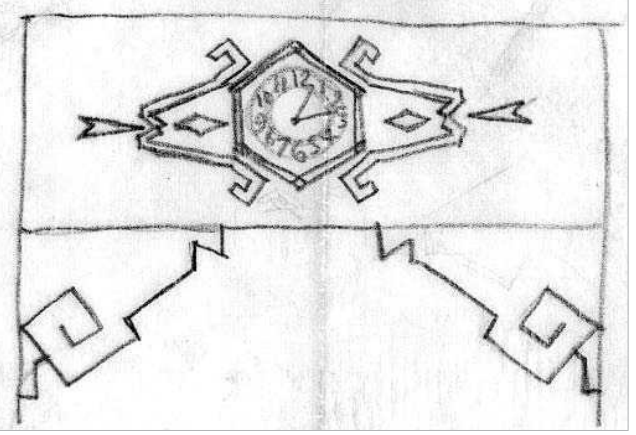

9 pav. Frumkinų parduotuvės ornamentika, laikrodžio ir iejjimo angos dekoravimo eskizas, 1922 m., KAA. F156 ap.1, b.8, I.23

Fig. 9. Frumkinai Store ornamentation, sketch of decorations of the watch and entrance opening, 1922. 
tiko krautuvèlès paskirčiai. Interjero stilistika buvo derinta prie viso pastato neoklasicistinių dekoro formų, arkinių durų angų, langų frontonèlių bei fasadą dalijančių karnizų ritmikos. Interjere suformuotos arkos proporcija atkartojo fasado ašyje esančio pagrindinio pastogès frontono arkos formą. Augalinio ornamento motyvas interjere pratęsia pagrindinio fasado frizinès juostos dekoro mintį.

Tautinio stiliaus bruožai Frumkinų parduotuvès interjero projekte: suplanavimas nesudètingas, tačiau interjerui būdingas puošnumas. Puošnumo ịspūdžiui pasiekti saikingai naudojami klasikinio orderio elementai. Medinès sienų apdailos plokštès buvo puoštos medžio raižiniais. Medis - pagrindine interjero apdailos medžiaga. Komercinès paskirties patalpose išryškejjo radikali barokinès voliutos bei lietuviškos tulpeles ir saulutès stilizacija.

\section{„Lietuvos“ viešbutis - $1925 \mathrm{~m}$.}

„Metropolio“ arba „Lietuvos“ viešbutị su restoranu Kaune (Laisvès al. 68/Daukanto g. 19) 1922 m. ịsigijo Užsienio reikalų ministerija ir Lietuvos Respublikos Ministrų tarybos nutarimu jis buvo paskirtas užsienio svečių klubui ịrengti (Lukšionytė 2001: 93). Galima daryti prielaidą, kad šis objektas turèjo ir politinių, ir reprezentacinių tikslų Lietuvos valstybingumui, šalies turtingumui ir modernumui deklaruoti. V. Dubeneckio sukurtas viešbučio interjero projektas yra prabangaus modernaus, europietiško viešbučio etalonas, kartu - tautinio stiliaus pavyzdys. J. Kančienès tekstuose apie V. Dubeneckio architektūrą buvo minèta, kad $1925 \mathrm{~m}$. V. Dubeneckio suprojektuotas, iki šių dienų iš dalies išlikęs, „Lietuvos“ viešbučio vestibiulis - vienas iš vertingesniu interjero pavyzdžiu tarpukario Lietuvoje: tamsaus medžio apdaila, tautiniai motyvai lubu puošyboje ir grindu raštuose (Kančienè 1988:). Reikia pastebėti, kad „Lietuvos“ viešbučio išlikusiame interjero projekte didžiąją dali sudaro V. Dubeneckio ranka piešti eskizai: baldų ir vestibiulio perspektyviniai vaizdai ${ }^{22}$. Iki šiol yra saugomos V. Dubeneckio surinktos iškarpos su viešbučių interjerų nuotraukomis iš XX a. pradžios europietiškų žurnalų ${ }^{23}$. Atkreiptinas demesys, kad tarp projekto dokumentacijos yra O. Rodeno muziejaus, esančio buvusiame Paryžiaus viešbutyje „Biron“, nuotrauka ${ }^{24}$.

\footnotetext{
${ }^{22}$ KAA. F156 ap.1, b.26.

${ }^{23}$ KAA. F156 ap.1, b.51.

${ }^{24}$ KAA. F156 ap.1, b.26 lap.18 (1731 m., tik pastačius „Biron“ viešbutị, jis buvo ypač puošniai įrengtas pagal rokoko stilių, vèliau, $1820 \mathrm{~m}$., ịrengtas pensionatas - mokykla mergaitèms
}

Viešbutis buvo pastatytas $1731 \mathrm{~m}$. Paryžiuje ir ypač puošniai įrengtas pagal rokoko (vèlyvojo baroko) stilių. Tai leidžia manyti, kad architektas žavèjosi šiuo stiliumi. Lietuvoje V. Dubeneckis minčių ir ịkvėpimo ieškojo baroko architektūros formose.

Vestibiulio perspektyvos eskizas (10 pav.) $)^{25}$ liudija apie puošnaus ir prabangaus interjero, turinčio klasicizmo bruožų, įspūdị. Minkštasuoliai vestibiulio eskize turi ampyrinès stilistikos: banguotos kojelių linijos ir voliutos formų porankiai. Tulpeliu ornamentu dekoruota frizo juosta yra ịreminta tarp virvele ornamentuotų karnizų. Klasicistiniu, jonèniniu kapiteliu puošta kolona ir piliastrai įremina klasicistinio dekoro bareljefą. Baldai eskizuose dekoruojami barokinemis formomis.

Iki šių dienų yra išlikę V. Dubeneckio piešti eskizai su skirtingais spintų, kẻdžių ir stalų variantais. Jų bendras bruožas - puošnumas: ryškus dekoras, karnizai, rifliuoto frizo juostos, ịsprūdiniai durų rèmai, juose ¡komponuoti reljefiniai barokiniai ornamentai, kuriuos

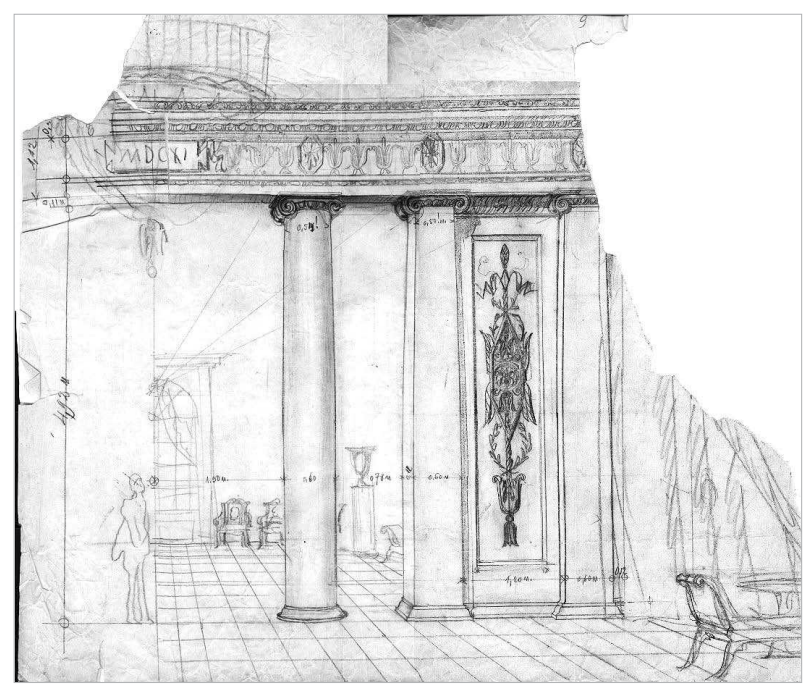

10 pav. „Lietuvos“ viešbutis - vestibiulio eskizas, 1925 m., KAA.F156 ap.1, b.26, I.9

Fig. 10. "Lietuva" hotel, drawing of the lobby interior, 1925.

iš aristokratišku šeimų. Tuo metu buvo sunaikinta visa rokoko stiliaus prabanga: veidrodžiai, puošnios, drožinètos medinès sienu plokštės. Vietoje prabangos buvo pristatyta koplyčia. 1905 m. Prancūzijoje atskyrus bažnyčią nuo valstybès, pensionatas bei mokykla buvo uždaryti. Patalpos buvo perplanuotos atskiru butu blokais. O. Rodenas išsinuomojo keletą patalpu apatiniame aukšte kaip skulptūrų saugyklą, o vèliau naudojo kaip kūrybine dirbtuve. 1909 m., būdamas savo šlovès viršūnejje, agitavo „Biron“ viešbutị tapti jo skulptūrų muziejumi. Po skulptoriaus mirties, 1919 m. buvusio viešbučio pastate atidarytas ir iki dabar veikia $\mathrm{O}$. Rodeno skulptūrų muziejus).

${ }^{25}$ KAA. F156 ap.1 b.26 lap.9. 
dar labiau paryškina ịvairiomis kryptimis derintos fanieruotès (arba medienos masyvo) raštai. Plastiškos linijos, kurių galai užsibaigia miniatiūrinėmis voliutomis, tarpusavyje jungiasi taip, kad susiformuoja ryškus rombas banguojančiomis sienelemis. Plastiško rombo ornamentas kai kurių baldų fasaduose jungiasi i grupes ir suformuoja ypač ryškų fasado dekorą. Spintų dekoro banguotas ornamentas turi rokailès ornamentui būdingos plastikos, tačiau, lyginant su baroko laikotarpio autentiškais analogais, jis yra ramesnis ir simetrizuotas. Durų įstiklinimas visada komponuojamas centrinėse duryse. Simetriją dar labiau paryškina isstiklinimo dekoravimas banguotų linijų ornamentais. Spintų kojelių rutulinè forma charakteringa barokinių baldų stiliui. Ieškant prabangesnio ir puošnesnio spintos fasado, kai kuriuose balduose virš karnizo buvo projektuotas barokinių formų frontonèlis ${ }^{26}$. Žmogaus ūgio modulis rodo, kad projektuojamų spintų aukštis galèjo būti daugiau nei $183 \mathrm{~cm}^{27}$.

Puošnios kèdès ir krèslai sudaro prabangos ir patogumo įspūdị. Dominuoja drožinèto medžio banguoti ornamentai. Plastiškas ir ryškus kẻdžių dekoras derinamas su spintų durų puošyba (11 pav. $)^{28}$. „Lietuvos“ viešbučio barokinių formų kèdèse ${ }^{29}$ aptinkame lietuviškų drožinių motyvą - virvelès ornamentą. Tokị patį motyvą V. Dubeneckis naudojo Karmèlavos bažnyčios altoriaus puošyboje. Ypatingu grakštumu ir barokui būdinga medžio drožinių plastika išsiskiria virvele puoštas krėslas aukšta atkalte (12 pav.). Šis baldas sudaro ir prabangos, ir patogumo ịspūdị. Kabinetinès

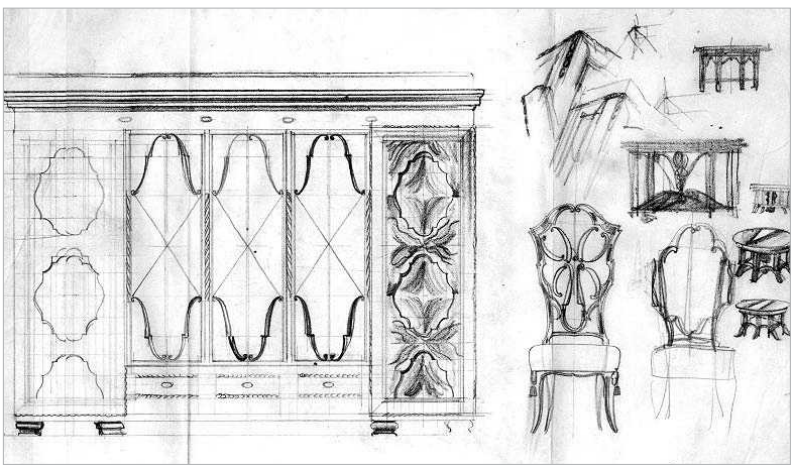

11 pav. „Lietuvos“ viešbutis - spintos, kèdès ir stalo eskizas, 1925 m., KAA.F156 ap.1, b.26, I.1

Fig. 11. "Lietuva" hotel - sketch of a wardrobe, table and chair, 1925.

\footnotetext{
${ }^{26}$ KAA. F156 ap.1 b.26, lap.4; lap.5; lap.10.

${ }^{27}$ KAA. F156 ap.1 b.26, lap.7.

${ }^{28}$ KAA. F156 ap.1 b.26, lap.1; lap.2; lap.11; lap.13; lap.17.

${ }^{29}$ KAA. F156 ap.1 b.26, lap.6; lap.12; lap.13.
}

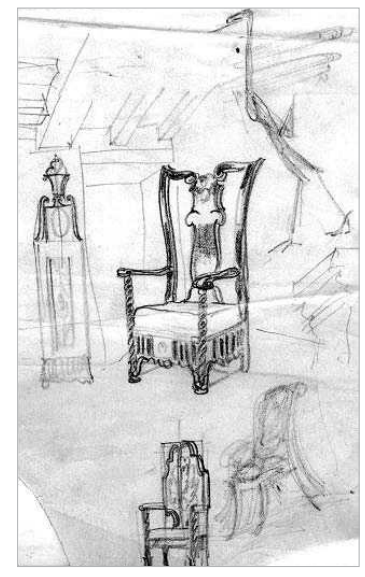

12 pav. „Lietuvos“ viešbutis - kèdès ir baldinio laikrodžio eskizas, 1925 m., KAA.F156 ap.1, b.26, I.13

Fig. 12. "Lietuva" hotel, drawings of a chair and furniture watch, 1925.

kèdès atramai ažūriškai dekoruoti panaudojamas spintu fasado ornamentikos motyvas. Kèdžiu atramu formos ir ažūro plastika turi rokailès ornamento bruožų ${ }^{30}$. Daugumoje eskizų aptinkame baroko stilistikai charakteringas banguotas, plastiškas linijas ir puošnias formas, nors randamas ir labiau geometrizuotas, art deco stilistikai artimas dekoravimo charakteris $(13 \text { pav. })^{31}$. Šiame piešinyje atsiskleidžia naujų, netipinių formų paieška, baroko ir modernaus stiliaus sintezès procesas.

Stalai „Lietuvos“ viešbučiui buvo projektuojami keleto tipų: kabinetinis stalas, valgomojo stalas ir kavos stalelis. Kabinetiniai stalai kaip ir spintos visuose eskizuose komponuoti simetrijos principu: po spintelę iš abiejų pusių. Spintelių durelès minimaliai derintos prie spintų durų dekoro. Labiau detalizuotuose brežiniuose reljefiniame įsprūdiniame rème matosi lygios plokštumos. Dalyje eskizų fasadinių durelių plokštuma puošta tik įsprūdiniu profiliu, kuris viršutinèje dalyje įrèmina nedidelị stalčiuką su užraktu ${ }^{32}$. Kitų rašomųjų stalų durelès dekoruotos vaisių ornamentais arba rombų motyvais. Dalis rašomųjų stalų projektuoti puslankiu išgaubtu stalviršiu centrinejje plokštumos dalyje, matyt, sèdejjimo patogumui pagerinti (13 pav. ${ }^{33}$. Dekoruojant dureles moderniu geometriniu ornamentu, atitinkamai ir stalviršio centrinès dalies išgaubimas keičiamas trapecijos formos igilinimu. Stalviršio centrinè dalis, matyt, buvo dengta audiniu (šiuo atveju nenurodyta medžiaga, bet dažniausiai tai būdavo natūralios odos inkliuzas, linoleumas arba gelumbè). Kai kurių spintelių vertikalios išorinès briaunos buvo papuoštos

\footnotetext{
${ }^{30}$ KAA. F156 ap.1 b.26, lap.1; lap.13.

${ }^{31}$ KAA. F156 ap.1, b.26, lap.14.

${ }^{32}$ KAA. F156 ap.1, b.26, lap.11.

${ }^{33}$ KAA. F156 ap.1, b.26, lap.14.
} 


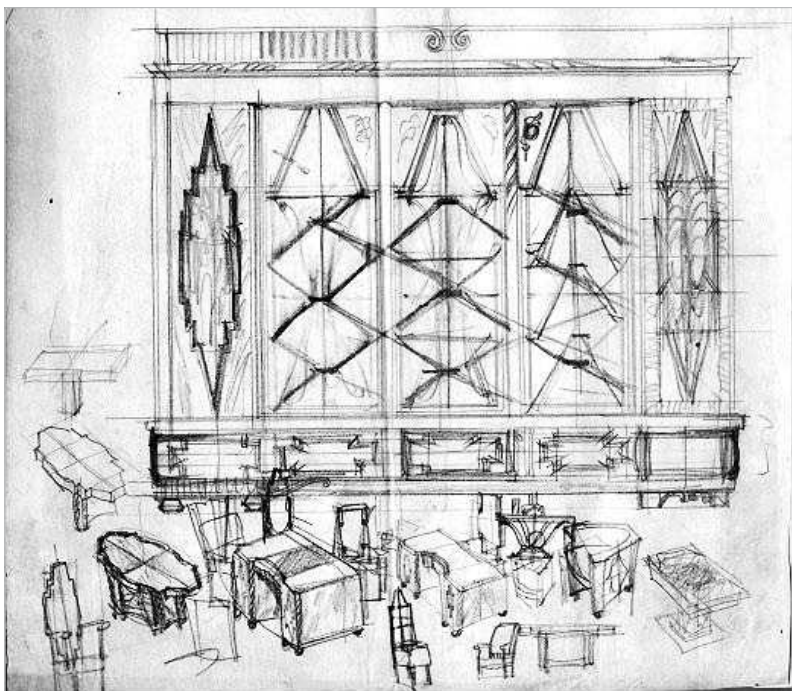

13 pav. „Lietuvos“ viešbutis - spintos ir stalu eskizai, 1925 m., KAA.F156 ap.1, b.26, I.14

Fig. 13. "Lietuva" hotel - drawings of a wardrobe and desks, 1925.

virveles ornamentu, derinant prie dalies projektuojamų kẻdžių ir krèslų. Savo tūriu ir konstrukcija visi rašomuju stalu variantai turi moderniu baldu formą, tačiau panaudotas dekoras jiems suteikè neoklasikai būdingos prabangos ir puošnumo.

Valgomojo ar kavos staleliai buvo projektuoti puošnesni ir sudètingesnès formos nei kabinetiniai stalai. Juose daug barokinių ir neoklasikinių formų kaip spintose ir kèdèse. Stalų kojos, drožinètos banguojančiais ir ryškiais ornamentais, pratęsia dominuojančią spintų ir kèdžių stilistiką. Greta apvalių ir ovalių stalviršių buvo projektuojami ir sudètingo, banguojančio perimetro paviršiai, formuojami iš aštuonių trikampių detalių. Visų stalviršių briaunos profiliuotos. Kai kuriuose eskizuose stalviršio briauna suapvalinta virvelès ornamentu. Stalų rèmai po stalviršiu dekoruojami rifliuotu paviršiumi. Puošniu tulpés ornamentu drožinèta apvalaus stalo koja $^{34}$ atkartoja vestibiulio frizo juostos motyvą.

Igyvendinus viešbučio projektą, buvo plačiai paplitusi nuomonè apie „Lietuvos“ viešbučio („Metropolio“) modernuma, puikuma ir neturejima sau lygiü ${ }^{35}$. Šis objektas tinkamai reprezentavo tarpukario Lietuvos architektūrą ir dizainą, reprezentavo Lietuvą kaip modernią, turtingą, europietišką valstybę.

\footnotetext{
${ }^{34}$ KAA. F156 ap.1, b.26, lap.3; lap.15.

${ }^{35}$ Metropolis. 1932. Naujas Žodis 7 (165): 136-137; Lietuvos viešbutis. 1930. Lietuvos aidas VI. 18: 10.
}

Tautinio stiliaus bruožai „Lietuvos“ viešbučio interjero projekte. Šiam interjerui būdingas puošnumas. Puošnumo įspūdžiui pasiekti kaip ir Frumkinų parduotuvès projekte saikingai naudojami klasikinio orderio elementai ir medžio raižiniai. Tamsaus medžio sienų apdailos plokštès - dominuojanti interjero apdailos medžiaga. Balduose gausiai naudojami medžio raižiniai. Puošnumas pasiekiamas ryškiomis plastiškomis linijomis ir naudojant tamsią medienos spalvą. Ornamentikos motyvai: barokinis - voliuta ir banguotų linijų motyvas bei tautinis ornamentas - virvele ir tulpe. Kompozicijoje dominuoja simetrija.

\section{Tautinio stiliaus paieškų proceso aptarimas}

Šiandien yra daug publikuotų mokslinių straipsnių, kuriuose tautinio stiliaus problema buvo nagrinèta skirtingais rakursais. Tautinemmis formomis pagrịstas profesionalus menas kèlè daug prieštaringų diskusijų tiek tarpukario Lietuvoje, tiek ir dabar. Geruosius ir abejotinus tautinio stiliaus ieškojimo aspektus analizavo architektūrologai ir menotyros tyrèjai. Greičiausiai dèl šių savybių L. Šatavičiūtè, nagrinejjusi šị fenomeną skirtingais aspektais, tautinị stiliu vadino dinamiška kategorija (Šatavičiūtè 2001: 84), G. Jankevičiūtè, tyrinèjusi dailę kaip politikos kalbą suformulavo pavadinimą: oficialus stilius (Jankevičiūtè 2002: 46). Vaidas Petrulis, analizavęs architektūros politikos apraiškas tarpukario Lietuvos periodikoje, taip pat nustate, jog tautinis stilius reprezentacineje plotmeje buvo dominuojanti teorine pozicija (Petrulis 2009: 126). Tad reikètų îvertinti faktą, kad atsirandant šiam stiliui būta ne vien tik patriotinis ar rekomendacinis, bet reikalavimo ir prievartos momentai taip pat. Pastarieji ryškiausiai pasireikšdavo valstybinių architektūros objektų srityje.

Liaudies meno, klasikinès architektūros ir modernumo sintezavimo taisyklių nebuvo ir nèra. Bet kokiu atveju architektūrinès stilizacijos procesas - sudètinga užduotis. Neanalizuojant stilizacijos neigiamų bruožų, galima teigti, kad V. Dubeneckis neapsiribojo vien tik XX a. pradžioje populiaria liaudies amatų tradicija: tautinès tapatybės ieškojo platesniu žvilgsniu, apimda mas profesionalią praeities architektūrą. V. Dubeneckio stilizacijos ir skirtingų architektūros stiliu sintezès procesas įrodo architekto priešinimąsi tarpukario Lietuvoje perdem propaguotai tiesmuko tautinio meno koncepcijai. 


\section{Išvados}

1. Priverstinis naujo, tautinę tapatybę patvirtinančio stiliaus paiešku procesas gan stipriai varžè menininkų bei architektụ kūrybos laisvę. Tautinès reprezentacijos reikalavimas ryškiausiai pasireikšdavo vykdant valstybinius užsakymus. XX a. pradžios Lietuvoje susiklosčiusi nacionalinio atgimimo situacija greta pozityvių turèjo ir neigiamų aspektų. Vienas iš jų buvo tas, kad tautinis stilius buvo formuojamas dirbtinai. Todèl tiesmukiškumas buvo neišvengiamas.

2. Nors ir turèdamas jau suformuotą, griežtą rusų akademinès klasikinių architektūros vertybių metodiką, V. Dubeneckis sugebëjo vykdyti ne mažiau griežtą lietuvių tautinès tapatybès reprezentavimo reikalavimą. Interjerų tautiniam stiliui apibūdinti sukūrè nors ir negausią, tačiau gan tikslią vizualinių ženklų ir simbolių sistemą. İ ją pateko: simetrija, nesudètingas suplanavimas, puošnumas, tuo tikslu apdailai naudotas tamsios spalvos medis ir ịvairiausi medžio raižiniai; medis - pagrindinè apdailos medžiaga, iš kurios buvo daromos medinès dailylentès arba medinès sienų apdailos plokštès; saikingai panaudoti klasikinio orderio elementai; ornamentika: tulpés, saules ir virveless motyvai, perimti iš lietuvių liaudies meno, banguotos linijos ir voliutos - iš praeities baroko architektūros.

\section{Literatūra}

Basanavičius, A. 1912. İžanga Jaroševičiaus albumui „Lietuviu kryžiai“. Vilnius.

Dirgèla, A. 1927. Meno Mokykla, 7 meno Dienos 5: 10.

Dubeneckis, V. 1925. Apie mūsų architektūrą, Baras 1: 89-95.

Galaunè, P. 1937. Dailininkas architektorius Vladimiras Dubeneckis, Studentu dienos 8: 6.

Galaune, P. 1970. Dailininkas architektas Vladimiras Dubeneckis. Penkeriems metams po jo mirties praslinkus, iš Straipsniu rinkinys: Dailès ir kultūros baruose. Vilnius: Vaga, 220-225.

Jankevičienè, A. 2007. Lietuvos medinés bažnyčios, koplyčios ir varpines. Vilnius: VDA leidykla.

Jankevičiūtè, G. 2002. Dailè kaip politikos kalba. Lietuva 1918-1940, Menotyra 2(27): 46-55.

Jankevičiūtè, G. 2003. Daile ir valstybè. Dailès gyvenimas Lietuvos respublikoje 1919-1940. Kaunas: NČDM.

Kančienè, J. 1988. Vladimiras Dubeneckis. Jubiliejinè kūrybos paroda, skirta 100-ioms gimimo metinèms, Parodos katalogas. Vilnius.

Lukšionytè, N. 1991. „Lietuvos“viešbutis Daukanto g. 21, iš Kauno architektūra. Vilnius: Mokslas, 82-83.

Lukšionytè, N. 1991. Apygardos teismas Laisvès al. 103, iš Kauno architektūra. Vilnius: Mokslas, 156-157.
Lukšionytė-Tolvaišienè, N. 2001. „Metropolio“viešbutis su restoranu, iš Gubernijos laikotarpis Kauno architektūroje. Kaunas: VDU leidykla, 93-94.

Lukšionytè-Tolvaišienè, N. 2001. Teismo rūmai ir pašto telegrafo kontora, iš Gubernijos laikotarpis Kauno architektūroje. Kaunas: VDU leidykla, 81-83.

Mačiulis, A. 1998. Tautinès architektūros paieškos (19191944), Urbanistika ir architektūra 22 (4): 154-159.

Margaitis, A. 1937. Butas ir baldai, Amatininkas 13-14: 200-201.

Margaitis, A. 1937. Butas ir baldai, Amatininkas 4: 57.

Metropolis. 1932. Naujas Žodis 7(165): 136-137.

Miškinis, A. 1988. Konferencija, skirta V. Dubeneckio gyvenimui ir kūrybai, Kauno tiesa 262 (12746): 3.

Mokslinès konferencijos, skirtos Vladimiro Dubeneckio gyvenimui ir kūrybai, medžiaga. 1988 spalio 25 d. Pranešimai. Lietuvos statybos ir architektūros mokslinio tyrimo institutas. Kaunas: Lietuvos kultūros fondo Kauno taryba.

Morkytè, J. 1981. Aukštosios dailès mokyklos raida Lietuvoje, iš Dailes institutas. Vilnius: Vaga, 5-28.

Mulevičiūtè, J. 2001. Modernizmo link. Kaunas: NČDM.

Petrulis, V. 2009. Architektūros politikos apraiškos Lietuvos tarpukario (1918-1940) periodikoje: tarp reprezentacijos ir socialinio teisingumo, Urbanistika ir architektūra 33(2): 126-134. doi:10.3846/1392-1630.2009.33.126-134

Ramovès rūmai. 1937. Kardas 8 (262): 187-189.

Senesnio tipo architektūros vidaus dekoravimo pavyzdys perspektyvoj. 1937. Iliustruotas Židinio priedas 5: 15.

Songaila, M. 1934. V. Dubeneckis kaipo dailininkas - architektorius, visuomenès veikèjas ir kaipo žmogus, Technika ir ükis 7: 221-227.

Stravinskas, A.; Sakalauskas, M. 1992. Lietuviu liaudies menas. III kn. Mažoji architektūra. Vilnius: Vaga.

Šatavičiūtè, L. 2001. Antano Tamošaičio tautinio stiliaus koncepcija, Menotyra 2(23): 81-85.

Šatavičiūtè, L. 2009. Patriotiškumo ženklai XX a. pirmosios pusès kasdienybès kultūroje, Menotyra 16 (3-4): 117-129.

Valentukonis, J. 1937. Apie sienų dekoravimo tradicijas Lietuvoje, Amatininkas 9: 135-136.

Valentukonis, J. 1937. Dažytojai - buto kultūros nešejai, Amatininkas 10: 145-147.

Valentukonis, J. 1937. Natūrali medžiaga ar imitacija moderniškame bute, Amatininkas 1: 10-11.

\section{SEARCH FOR THE NATIONAL STYLE IN VLADIMIR DUBENECKY'S PUBLIC INTERIORS}

\section{Preišegalavičienè}

Abstract. The paper is dedicated to the famous Lithuanian interwar architect, painter, set designer, teacher Vladimir Dubenecky (1888-1932). Russian-born artist who lived and worked in Kaunas (in 1919-1932), has left for Lithuania significant heritage of creative work. One of the unique features of V. Dubenecky's creative biography was that, being not a Lithuanian, he became the first seeker for the Lithuanian 
national style in architecture and interior design. The part of V. Dubenecky's projects, which reflects search for the national style in the interior design, is discussed in the paper. Three public interiors designed by V. Dubenecky are selected for a review (Karmèlava Church (1919), Frumkinai Store (1922) and "Lietuva" hotel (also named "Metropolis" hotel) (1925) as well as their interaction with the national style which was expressed in the Lithuanian interwar architecture. Representativeness, as one of the most characteristic conceptual aspirations in public interior, is also discussed.

Keywords: interwar interior, history of interiors, furniture history, national style, national identity, Vladimir Dubenecky.

\section{LINA PREIŠEGALAVIČIENĖ}

Interior architect-designer and head of JS Company "Arkija". Savanoriu pr. 184, 44150 Kaunas, Lithuania.

E-mail: prei.lina@gmail.com.

First degree in Architecture, Vilnius Institute (now Academy) of Fine Arts, 1989. Publications: authors or co-author of architectural and interior projects. Research interests: interwar-period interior design, history of furniture design. 